University of Nebraska - Lincoln

DigitalCommons@University of Nebraska - Lincoln

\title{
Production Characteristics and Body Composition of Juvenile Cobia Fed Three Different Commercial Diets in Recirculating Aquaculture Systems
}

\author{
Charles R. Weirich \\ United States Department of Agriculture, cweirich@aquagrn.com \\ Paul S. Wills \\ Florida Atlantic University \\ Richard M. Baptiste \\ Florida Atlantic University \\ Marty A. Riche \\ United States Department of Agriculture
}

Follow this and additional works at: https://digitalcommons.unl.edu/usdaarsfacpub

Part of the Agricultural Science Commons

Weirich, Charles R.; Wills, Paul S.; Baptiste, Richard M.; and Riche, Marty A., "Production Characteristics and Body Composition of Juvenile Cobia Fed Three Different Commercial Diets in Recirculating Aquaculture Systems" (2010). Publications from USDA-ARS / UNL Faculty. 604.

https://digitalcommons.unl.edu/usdaarsfacpub/604

This Article is brought to you for free and open access by the U.S. Department of Agriculture: Agricultural Research Service, Lincoln, Nebraska at DigitalCommons@University of Nebraska - Lincoln. It has been accepted for inclusion in Publications from USDA-ARS / UNL Faculty by an authorized administrator of DigitalCommons@University of Nebraska - Lincoln. 


\title{
Production Characteristics and Body Composition of Juvenile Cobia Fed Three Different Commercial Diets in Recirculating Aquaculture Systems
}

\author{
Charles R. Weirich* \\ U.S. Department of Agriculture, Agricultural Research Service, \\ 5600 US 1 North, Fort Pierce, Florida 34946, USA \\ Paul S. Wills and Richard M. Baptiste \\ Center for Aquaculture and Stock Enhancement, Harbor Branch Oceanographic Institute at \\ Florida Atlantic University, 5600 US 1 North, Fort Pierce, Florida 34946, USA \\ Marty A. Riche \\ U.S. Department of Agriculture, Agricultural Research Service, \\ 5600 US 1 North, Fort Pierce, Florida 34946, USA
}

\begin{abstract}
The effect of feeding three commercial diets on production characteristics and body composition of juvenile cobia Rachycentron canadum reared using recirculating aquaculture systems (RASs) was assessed in a 56-d growth trial. Juvenile cobia (mean weight $\pm \mathrm{SE}, 29.2 \pm 0.7 \mathrm{~g}$ ) were stocked into three $8-\mathrm{m}^{3}$ tanks in each of four RASs at an initial density of $1.2 \mathrm{~kg} / \mathrm{m}^{3}$. After stocking, fish were fed one of three commercial diets: Hybrid Striped Bass diet (HSB; $44 \%$ protein, $12 \%$ lipid), Finfish Gold diet (GOLD; $42 \%$ protein, $16 \%$ lipid), or Marine Grower diet (MG; $50 \%$ protein, $15 \%$ lipid), all at a targeted feed rate of $3-5 \%$ of body weight per day. At 2-week intervals, $10 \%$ of the population of each tank was collected to determine mean weight, weight gain, specific growth rate (SGR), feed conversion efficiency (FCE), and biomass. At the end of the rearing trial, the entire population of each tank was harvested to determine production characteristics and survival. In addition, fish were sampled to determine whole-body composition, hepatosomatic index, intraperitoneal fat ratio, energy retention (ER), protein efficiency ratio (PER), and protein productive value (PPV). Final weight $(311.0 \mathrm{~g})$, weight gain $(281.8 \mathrm{~g})$, SGR (4.23\% per day), FCE $(85.7 \%)$, biomass $\left(11.20 \mathrm{~kg} / \mathrm{m}^{3}\right)$, and ER $(32.7 \%)$ of fish fed the MG diet were significantly greater than those of fish fed the HSB and GOLD diets. No differences in survival, gross energy, ash, or crude lipid content existed among fish fed the three diets. Lowest dry matter content, lowest PPV, and highest protein content were observed in fish fed the HSB diet. Highest PER was observed in fish fed the GOLD diet. Although the cost of production per kilogram for rearing juvenile cobia with the MG diet would be greater, this cost could be offset by the $15 \%$ reduction in rearing time required as compared with the HSB and GOLD diets.
\end{abstract}

Interest in culture of the cobia Rachycentron canadum, a migratory marine pelagic finfish and lone member of the family Rachycentridae (Smith 1986), has increased greatly in the United States over the course of the last decade. Cobia possess a number of attributes desirable for a commercially cultured fish. They can be spawned in captivity with or without hormonal induction (Dodd 2001; Franks et al. 2001; Arnold et al. 2002; Kilduff et al. 2002; Weirich et al. 2006), and protocols for larval rearing have been developed for the mass production of weaned juveniles to ensure a consistent and reliable supply of seed stock for on-growing operations (Liao et al. 2001; Holt et al. 2007; Benetti et al. 2008). Under suitable conditions,

\footnotetext{
* Corresponding author: cweirich@aquagrn.com
}

Received March 3, 2009; accepted May 29, 2009 Published online October 22, 2009 cobia exhibit extremely rapid growth rates (Chou et al. 2001, 2004; Weirich et al. 2004; Lunger et al. 2006), attaining weights of 4-6 kg in less than 1 year (Chou et al. 2004; Liao et al. 2004); they adapt well to confinement and readily accept formulated feeds (Schwarz et al. 2004; Weirich et al. 2004), and they are of excellent food quality, with high consumer appeal (McClane 1974; Chen 2001; Oesterling 2001; Rickards 2001; Shiau 2007). These characteristics, coupled with the successful expansion and growth of cobia aquaculture in Taiwan, China, and southeast Asia (Liao et al. 2001, 2004; Liao 2003; De Silva and Phillips 2007), have served as stimulants for industry development elsewhere, including Central America and the Caribbean (Benetti et al. 2007, 2008).

Although the vast majority of farmed cobia are currently produced by net-pen rearing operations, establishment of land-based recirculating aquaculture 
system (RAS) technologies for cobia production could mitigate some of the issues associated with development of net-pen culture in U.S. waters, such as permitting, effluent discharge regulations, and restrictions on the use of coastal and offshore environments (Weirich et al. 2003). However, to be a feasible alternative, RASs must be both biologically and economically viable. Regarding the latter, because feed expense generally accounts for over $50 \%$ of annual operational costs for marine finfish aquaculture operations (Tucker 1998), development of cost-effective feeds and feeding strategies are of great importance to future development of cobia aquaculture, especially if practiced using RAS technologies.

While not yet as comprehensive as that previously established for other cultured marine finfish species, the scientific literature available on cobia nutrition has grown considerably in recent years. To date, several studies have been conducted with cobia on topics including ingredient digestibility (Zhou et al. 2004), dietary methionine and lysine requirements (Zhou et al. 2006, 2007), dietary fish meal replacement (Chou et al. 2004; Zhou et al. 2005; Lunger et al. 2006, 2007a, 2007b), and optimal protein and lipid levels (Chou et al. 2001; Wang et al. 2005; Craig et al. 2006). Nonetheless, no commercial diets specifically for feeding cobia are currently available in the United States; therefore, producers must use diets developed for other finfish species. The present study was conducted to compare the effect of three available commercial diets with different protein and lipid contents on the production characteristics and body composition of juvenile cobia reared in RASs.

\section{Methods}

Experimental systems. - Studies were conducted in four replicate RASs located within the U.S. Department of Agriculture (USDA), Agricultural Research Service (ARS) Sustainable Tank Aquaculture Recirculating Research Facility on the campus of Harbor Branch Oceanographic Institute (HBOI) at Florida Atlantic University (FAU), Fort Pierce. Each $45-\mathrm{m}^{3}$ RAS consisted of four $8-\mathrm{m}^{3}$ round fiberglass culture tanks engineered with a Cornell dual-drain system (Timmons et al. 1998). Primary solids removal was accomplished by a $600-\mathrm{L}$ Wave 36 vortex filter (W. Lim Corp., Mira Loma, California) attached to each tank and a centralized Hydrotech 801 drum filter equipped with a $40-\mu \mathrm{m}$ screen (Water Management Technologies, Inc., Baton Rouge, Louisiana). Water was circulated by two $1.5-\mathrm{kW}$ pumps through two 0.7 $\mathrm{m}^{3}$ propeller-washed bead filters (PWBF; Aquaculture Systems Technologies, New Orleans, Louisiana) for biofiltration and fine solids removal. Each RAS also included a $2.2-\mathrm{m}^{3}$ oxygen injection cone (Waterline Ltd., Charlottetown, Prince Edward Island), two degassing towers, and a 520-W multi-lamp ultraviolet sterilization unit (Emperor Aquatics, Inc., Pottstown, Pennsylvania). Plastic nets $(0.95-\mathrm{cm}$ mesh) were placed over each tank to prevent fish escape. A $12 \mathrm{~h}$ light : 12 $\mathrm{h}$ dark photoperiod (surface light level $=50-200 \mathrm{~lx}$ ) was provided with overhead fluorescent lights. During the study, each of the two PWBF units servicing each RAS was backwashed every other day on a rotating schedule (Pfeiffer and Malone 2006). Settled sludge was removed from PWBF units, wave vortex filters, and tank-bottom drain lines daily. Daily water loss from systems was less than $4 \%$ of total system volume. Water used to supply the RASs was obtained from two sources located on the campus of HBOI-FAU. Saline water was pumped from a 7-m-deep well adjacent to the Indian River Lagoon, and brackish water was obtained from a 600-m-deep well. Both water sources were subjected to biological and mechanical filtration before entry into experimental units via float valves installed in system sumps. During the study, salinity of the saline- and brackish-water sources ranged from 28 to $33 \mathrm{~g} / \mathrm{L}$ and from 1.0 to $1.5 \mathrm{~g} / \mathrm{L}$, respectively.

Experimental design, husbandry, and sampling protocol.-At the start of the 56-d rearing trial, juvenile cobia reared from recently metamorphosed postlarvae obtained from the Rosenstiel School of Marine and Atmospheric Science, University of Miami, were stocked into three tanks in each of the four RASs at an initial nominal density of $1.2 \mathrm{~kg} / \mathrm{m}^{3}$, equivalent to 324 fish/tank. Mean ( \pm SE) weight of fish at stocking was $29.2 \pm 0.7 \mathrm{~g}(n=100)$. Dietary treatments were assigned using a randomized complete block design with four replicates per treatment. At initiation of the rearing trial, 15 fish were collected and preserved at $-20^{\circ} \mathrm{C}$ for subsequent whole-body composition analysis. After stocking, fish were hand fed one of three commercial diets: Hybrid Striped Bass (HSB; 44\% protein, $12 \%$ lipid; floating pellet), Finfish Gold (GOLD; $42 \%$ protein, $16 \%$ lipid; floating pellet), or Marine Grower (MG; $50 \%$ protein, $15 \%$ lipid; slowsinking pellet) twice daily at 0900 and 1500 hours. All diets were manufactured by Zeigler Brothers, Inc., Gardners, Pennsylvania. Fish were allowed $30 \mathrm{~min}$ to consume allotted rations at each feeding period. Food particle size of each diet fed from day 1 through day 42 was $3.0 \mathrm{~mm}$; thereafter, fish were fed $5.0-\mathrm{mm}$ diets until the conclusion of the trial. The targeted feed rate throughout the study ranged from $3 \%$ to $5 \%$ of body weight per day, which was achieved by increasing feed distributed to each tank by a factor of $4 \%$ daily. At stocking and at 2-week intervals thereafter, $10 \%$ of the fish population of each tank was randomly collected 
and individual weights were recorded to the nearest 1.0 $\mathrm{g}$ to determine production characteristics: mean weight, weight gain, specific growth rate (SGR), feed conversion efficiency (FCE), and biomass. Specific growth rate was calculated by using the formula: $\left[\log _{10}\left(W_{t}\right)-\right.$ $\left.\log _{10}\left(W_{i}\right)\right] / t \times 100$ (where $W_{t}=$ weight at the end of a sampling period, $W_{i}=$ initial weight, and $t=$ length of time of the sampling period in days). Feed conversion efficiency was calculated by using the formula: [(wet weight gain, g)/(dry weight of feed fed, g)] $\times 100$. Mean weight of fish from each treatment was used to recalculate appropriate feed rations. Mortalities were removed and recorded daily as necessary to estimate percent survival at each sampling period. At the termination of the rearing trial, the entire population of each tank was harvested and group weights of 20-30 fish each were obtained to determine production characteristics and survival. In addition, five fish were obtained from each tank to determine the hepatosomatic index $(\mathrm{HSI}=[$ liver weight/body weight $] \times 100)$ and intraperitoneal fat ratio (IPF $=$ [intraperitoneal fat weight/body weight $] \times 100$ ), and 15 fish were collected and preserved at $-20^{\circ} \mathrm{C}$ for subsequent whole-body composition analysis. Total length (TL) of individually weighed fish from each tank at stocking and at termination was measured to determine condition factor $(K)$ using the formula: $K=100 \times\left(W / L^{3}\right)$, where $W$ is weight $(\mathrm{g})$ and $L$ is TL $(\mathrm{cm})$.

Whole-body composition and nutritional indices.Standard procedures were used for determining proximate components of fish and the diet fed during the rearing trial (AOAC 2003). Pooled whole-body samples were minced in a meat grinder and further homogenized using mortar and pestle. Two samples from each homogenized pool were taken for moisture analysis and dried at $105^{\circ} \mathrm{C}$ for $24 \mathrm{~h}$. Tissues remaining in the pooled samples were analyzed for crude protein (CP), crude lipid (CL), ash, and gross energy (GE). Nitrogen was determined by combustion (TruSpec Nelemental analyzer; Leco Corp., St. Joseph, Michigan), and $\mathrm{CP}$ was calculated as $\mathrm{N} \times 6.25$. Ash was determined after incineration at $600^{\circ} \mathrm{C}$ for $2 \mathrm{~h}$. Crude lipid was determined gravimetrically after chloroformmethanol extraction (Bligh and Dyer 1959) in a Soxhlet apparatus. Gross energy was determined by adiabatic bomb calorimetry (Parr Model 1266; Parr Instruments Co., Moline, Illinois). In addition to proximate components, energy retention (ER), protein efficiency ratio (PER), and protein productive value (PPV) were determined. Energy retention was calculated using the formula: $\left(W_{t} \times E_{t}-W_{i} \times E_{i}\right) / \mathrm{FI} \times E$ (where $W_{\mathrm{t}}=$ weight at the end of a sampling period; $W_{i}$ $=$ initial weight; $\mathrm{FI}=$ feed intake; and $E, E_{t}$, and $E_{i}=$ energy content of the diet, fish at termination, and fish at initiation of the rearing trial, respectively). The PER was calculated using the formula: (wet weight gain, g)/ (protein intake, g). The PPV was calculated using the formula: $\left(W_{t} \times P_{t}-W_{i} \times P_{i}\right) / \mathrm{FI} \times P$ (where $P, P_{t}$, and $P_{i}=$ protein content of the diet, fish at termination, and fish at initiation of the rearing trial, respectively).

Water quality.-Temperature, salinity, and $\mathrm{pH}$ of each RAS sump and dissolved oxygen of each culture tank were measured twice daily at 0900 and 1700 hours during the rearing trial. Total ammonia nitrogen (TAN), nitrite-nitrogen $\left(\mathrm{NO}_{2}-\mathrm{N}\right)$, and alkalinity of each RAS were measured daily between 1000 and 1200 hours. Temperature and dissolved oxygen were measured using a Hach LDO HQ10 meter (Hach Co., Loveland, Colorado), and salinity and $\mathrm{pH}$ were measured using a YSI 556 meter (YSI, Inc., Yellow Springs, Ohio). Concentrations of TAN and $\mathrm{NO}_{2}-\mathrm{N}$ were determined via Hach colorimetric assays (methods 8155 and 8153, respectively) using a Hach D/R 2500 spectrophotometer. Alkalinity was determined using the Hach digital titration method 8203. Water temperature and salinity ranged from $27.0^{\circ} \mathrm{C}$ to $30.5^{\circ} \mathrm{C}$ and from 25.0 to $30.4 \mathrm{~g} / \mathrm{L}$, respectively. Postfeeding dissolved oxygen levels were maintained at above $80 \%$ saturation. Levels of TAN and $\mathrm{NO}_{2}-\mathrm{N}$ were each maintained at levels below $0.4 \mathrm{mg} / \mathrm{L}$. Alkalinity was maintained at approximately $300 \mathrm{mg} / \mathrm{L}$ as $\mathrm{CaCO}_{3}$. The $\mathrm{pH}$ ranged from 7.1 to 8.2 . Sodium bicarbonate was added daily to systems to maintain alkalinity levels. To reduce the potential for parasitic infections, copper sulfate was added daily to experimental systems to maintain a level of $0.25 \mathrm{mg} / \mathrm{L}\left(\right.$ as $\left.\mathrm{Cu}^{2+}\right)$. Concentrations were verified daily with a copper test kit (Red Sea, Ellat, Israel).

Statistical analyses.- Statistical analyses were performed using SigmaStat version 3.0 (SPSS, Inc., Chicago, Illinois). Percentage data were arcsine, square-root transformed before analysis. All data were subjected to analysis of variance, and means separation was achieved using Tukey's studentized range test at a significance level $\alpha$ of 0.05 .

\section{Results}

With the exception of feed fed at day 14 and survival throughout the rearing trial, significant differences in measured production variables were evident at each sampling date and at the termination of the trial (Table 1). Final mean weight of juvenile cobia fed the MG diet $(311.0 \mathrm{~g})$ was significantly greater than that of fish fed the HSB (212.0 g) and GOLD (216.6 g) diets. Final weight gain of fish fed the MG diet $(281.8 \mathrm{~g})$ was greater $(P<0.001)$ that that of fish fed the HSB $(182.8$ g) and GOLD (187.4 g) diets. The SGR of juvenile cobia fed each diet decreased only slightly on a 
TABLE 1.-Weight, weight gain, specific growth rate (SGR), feed conversion efficiency (FCE), feed fed, and survival of juvenile cobia (initial weight $=29.2 \mathrm{~g}$ ) fed three different commercial diets for $56 \mathrm{~d}$ in recirculating aquaculture systems (see text for description of HSB, GOLD, and MG diets). Values (mean $\pm \mathrm{SE}$ ) within columns for each sample day that share the same letter are not significantly different $(P>0.05)$.

\begin{tabular}{llrrrrrr}
\hline Day & Diet & Weight $(\mathrm{g})$ & Weight gain $(\mathrm{g})$ & SGR $(\% / \mathrm{d})$ & FCE $(\%)$ & Feed fed $(\mathrm{g} /$ fish) & Survival $(\%)$ \\
\hline \multirow{2}{*}{14} & HSB & $52.4 \pm 0.8 \mathrm{y}$ & $23.3 \pm 0.5 \mathrm{y}$ & $4.19 \pm 0.06 \mathrm{y}$ & $70.8 \pm 1.4 \mathrm{y}$ & $32.9 \pm 0.1 \mathrm{z}$ & $99.6 \pm 0.2 \mathrm{z}$ \\
& GOLD & $54.5 \pm 0.8 \mathrm{y}$ & $25.3 \pm 0.7 \mathrm{y}$ & $4.46 \pm 0.09 \mathrm{y}$ & $76.6 \pm 2.2 \mathrm{y}$ & $33.1 \pm 0.1 \mathrm{z}$ & $99.0 \pm 0.3 \mathrm{z}$ \\
& MG & $58.7 \pm 0.9 \mathrm{z}$ & $29.5 \pm 0.5 \mathrm{z}$ & $4.99 \pm 0.06 \mathrm{z}$ & $89.8 \pm 1.6 \mathrm{z}$ & $33.0 \pm 0.1 \mathrm{z}$ & $99.4 \pm 0.2 \mathrm{z}$ \\
28 & HSB & $84.5 \pm 1.2 \mathrm{x}$ & $55.3 \pm 0.7 \mathrm{x}$ & $3.80 \pm 0.03 \mathrm{x}$ & $67.9 \pm 0.9 \mathrm{y}$ & $81.4 \pm 0.2 \mathrm{x}$ & $99.3 \pm 0.3 \mathrm{z}$ \\
& GOLD & $92.5 \pm 1.3 \mathrm{y}$ & $63.3 \pm 2.2 \mathrm{y}$ & $4.12 \pm 0.08 \mathrm{y}$ & $75.0 \pm 2.4 \mathrm{y}$ & $84.4 \pm 0.3 \mathrm{y}$ & $98.9 \pm 0.4 \mathrm{z}$ \\
& MG & $110.3 \pm 1.5 \mathrm{z}$ & $81.1 \pm 1.9 \mathrm{z}$ & $4.75 \pm 0.06 \mathrm{z}$ & $91.5 \pm 2.3 \mathrm{z}$ & $88.7 \pm 0.3 \mathrm{z}$ & $99.1 \pm 0.3 \mathrm{z}$ \\
42 & HSB & $135.5 \pm 2.2 \mathrm{x}$ & $106.4 \pm 3.8 \mathrm{x}$ & $3.66 \pm 0.07 \mathrm{x}$ & $69.5 \pm 2.5 \mathrm{y}$ & $153.0 \pm 0.4 \mathrm{y}$ & $99.3 \pm 0.3 \mathrm{z}$ \\
& GOLD & $151.9 \pm 2.6 \mathrm{y}$ & $122.7 \pm 3.6 \mathrm{y}$ & $3.93 \pm 0.06 \mathrm{y}$ & $75.6 \pm 1.7 \mathrm{y}$ & $156.3 \pm 1.6 \mathrm{y}$ & $98.9 \pm 0.4 \mathrm{z}$ \\
& MG & $194.6 \pm 3.3 \mathrm{z}$ & $165.4 \pm 3.9 \mathrm{z}$ & $4.51 \pm 0.05 \mathrm{z}$ & $89.5 \pm 1.9 \mathrm{z}$ & $184.9 \pm 0.6 \mathrm{z}$ & $99.1 \pm 0.3 \mathrm{z}$ \\
56 & HSB & $212.0 \pm 3.2 \mathrm{y}$ & $182.8 \pm 3.2 \mathrm{y}$ & $3.54 \pm 0.03 \mathrm{y}$ & $69.9 \pm 0.8 \mathrm{y}$ & $261.5 \pm 1.6 \mathrm{y}$ & $98.9 \pm 0.5 \mathrm{z}$ \\
& GOLD & $216.6 \pm 3.7 \mathrm{y}$ & $187.4 \pm 3.7 \mathrm{y}$ & $3.58 \pm 0.03 \mathrm{y}$ & $70.8 \pm 0.4 \mathrm{y}$ & $264.6 \pm 4.0 \mathrm{y}$ & $98.8 \pm 0.8 \mathrm{z}$ \\
& MG & $311.0 \pm 3.3 \mathrm{z}$ & $281.8 \pm 3.3 \mathrm{z}$ & $4.23 \pm 0.02 \mathrm{z}$ & $85.7 \pm 0.5 \mathrm{z}$ & $329.1 \pm 5.4 \mathrm{z}$ & $97.9 \pm 1.2 \mathrm{z}$ \\
\hline
\end{tabular}

temporal basis. Fish fed the MG diet exhibited significantly higher SGR values than fish fed the HSB and GOLD diets at each sampling period and at the termination of the trial. Final SGRs of fish fed the HSB, GOLD, and MG diets were 3.54, 3.58, and $4.23 \%$ per day, respectively. The FCE of fish fed each diet also remained constant during the trial. Juvenile cobia fed the MG diet had greater FCE values at each sampling period and at the conclusion of the trial than fish fed the HSB and GOLD diets $(P<0.001)$. Final FCE values of fish fed the HSB, GOLD, and MG diets were $69.9,70.8$, and $85.7 \%$, respectively. The amount of feed fed to fish of each treatment was significantly different at days 28, 42, and 56. The total amount of feed fed to fish receiving the MG diet during the trial $(329.1 \mathrm{~g})$ was greater than the amount fed to fish receiving the HSB (261.5 g) or GOLD (264.6 g) diet ( $P$ $<0.001)$. Tank biomass of fish fed the MG diet was significantly greater than that of fish fed the HSB and GOLD diets at each sampling period and also at the end of the trial. Final tank biomasses of fish fed the HSB, GOLD, and MG diets were 7.35, 7.53, and 11.20 $\mathrm{kg} / \mathrm{m}^{3}$, respectively. Final survival rates of fish fed the

TABLE 2.-Proximate composition of commercial diets fed to juvenile cobia during the experimental rearing trial (see text for description of diets). Values (mean $\pm \mathrm{SE}$; expressed on a dry-weight basis) within a row sharing the same letter are not significantly different $(P>0.05)$.

\begin{tabular}{lrrr}
\hline & \multicolumn{3}{c}{ Diet } \\
\cline { 2 - 4 } \multicolumn{1}{c}{ Variable } & \multicolumn{1}{c}{ HSB } & \multicolumn{1}{c}{ GOLD } & \multicolumn{1}{c}{ MG } \\
\hline Gross energy (cal/g) & $5,063 \pm 29 \mathrm{y}$ & $5,338 \pm 21 \mathrm{z}$ & $5,237 \pm 20 \mathrm{z}$ \\
Dry matter (\%) & $89.3 \pm 0.1 \mathrm{y}$ & $89.9 \pm 0.1 \mathrm{z}$ & $90.1 \pm 0.1 \mathrm{z}$ \\
Ash (\%) & $8.3 \pm 0.2 \mathrm{y}$ & $7.2 \pm 0.2 \mathrm{x}$ & $10.9 \pm 0.0 \mathrm{z}$ \\
Crude protein (\%) & $46.9 \pm 0.1 \mathrm{y}$ & $43.2 \pm 0.1 \mathrm{x}$ & $54.7 \pm 0.3 \mathrm{z}$ \\
Crude lipid (\%) & $16.4 \pm 0.1 \mathrm{z}$ & $13.8 \pm 0.6 \mathrm{z}$ & $9.9 \pm 0.8 \mathrm{y}$ \\
\hline
\end{tabular}

HSB, GOLD, and MG diets were 98.9, 98.8, and $97.9 \%$, respectively.

Initial $K$ of fish measured at stocking was $0.491 \pm$ 0.03. Final $K$ was $0.729 \pm 0.01$ for fish fed the HSB diet, $0.732 \pm 0.07$ for fish fed the GOLD diet, and $0.716 \pm 0.06$ for fish fed the MG diet. No significant differences in $K$ existed between dietary treatments.

Proximate composition of the commercial diets fed to fish during the rearing trial is shown in Table 2 . The HSB diet contained significantly lower GE (5,063 cal/ g) and dry matter (89.3\%) content than did the GOLD and MG diets. Ash and CP content of each diet was significantly different, and both variables were lowest in the GOLD diet ( $7.2 \%$ and $43.2 \%$, respectively). Crude protein level of the HSB and MG diets was $46.9 \%$ and $54.7 \%$, respectively. Crude lipid content of the MG diet $(9.9 \%)$ was lower than that of the HSB (16.4\%) and GOLD (13.8\%) diets $(P=0.01)$.

Whole-body composition of juvenile cobia sampled from each dietary treatment at the conclusion of the rearing trial is presented in Table 3. No differences in $\mathrm{GE}$, ash, or CL content existed among fish fed the three diets assessed. The CL content of fish fed HSB,

TABLE 3.-Whole-body composition of juvenile cobia fed three different commercial diets for $56 \mathrm{~d}$ in recirculating aquaculture systems (see text for description of diets). Values (mean $\pm \mathrm{SE}$; expressed on a dry-weight basis) within a row sharing the same letter are not significantly different $(P>$ $0.05)$.

\begin{tabular}{lccr}
\hline & \multicolumn{3}{c}{ Diet } \\
\cline { 2 - 4 } \multicolumn{1}{c}{ Variable } & HSB & GOLD & \multicolumn{1}{c}{ MG } \\
\hline Gross energy (cal/g) & $6,034 \pm 47 \mathrm{z}$ & $6,019 \pm 42 \mathrm{z}$ & $6,071 \pm 57 \mathrm{z}$ \\
Dry matter (\%) & $29.1 \pm 0.2 \mathrm{y}$ & $31.6 \pm 0.3 \mathrm{z}$ & $32.2 \pm 0.2 \mathrm{z}$ \\
Ash (\%) & $10.0 \pm 0.3 \mathrm{z}$ & $9.8 \pm 0.6 \mathrm{z}$ & $9.2 \pm 0.4 \mathrm{z}$ \\
Crude protein (\%) & $55.5 \pm 0.3 \mathrm{z}$ & $50.7 \pm 0.4 \mathrm{y}$ & $51.9 \pm 0.2 \mathrm{y}$ \\
Crude lipid (\%) & $23.6 \pm 2.9 \mathrm{z}$ & $28.4 \pm 3.2 \mathrm{z}$ & $26.6 \pm 1.1 \mathrm{z}$ \\
\hline
\end{tabular}


GOLD, and MG diets was 23.6, 28.4, and 26.6\%, respectively. Dry matter content of fish fed the HSB diet $(29.1 \%)$ was significantly lower than that of fish fed the GOLD (31.6\%) and MG (32.2\%) diets. The CP content of fish fed the HSB diet $(55.5 \%)$ was greater $(P$ $<0.001)$ than that of fish fed the GOLD $(50.7 \%)$ and MG (51.9\%) diets.

Significant differences existed among dietary treatments in ER, PER, PPV, HSI, and IPF (Table 4). The ER of fish fed the MG diet (32.7\%) was significantly greater than that of fish fed the HSB $(24.8 \%)$ and GOLD (26.1\%) diets. The PER of fish fed each diet was different $(P<0.001)$ and was highest for fish fed the GOLD diet (1.64). The PER was 1.49 for fish fed the HSB diet and 1.57 for fish fed the MG diet. Fish fed the HSB diet had a significantly lower PPV $(30.2 \%)$ than did fish fed the GOLD (32.9\%) and MG $(32.8 \%)$ diets. Fish fed the MG diet had a lower $(P<$ $0.001)$ HSI (4.29\%) than fish fed the HSB (4.95\%) and GOLD (5.33\%) diets. Fish fed the MG diet had a significantly higher IPF $(0.18 \%)$ than fish fed either the HSB $(0.05 \%)$ or GOLD $(0.08 \%)$ diet.

\section{Discussion}

The aim of this study was to compare three different diets that were commercially available in North America, that had different protein and lipid levels, and that were specifically formulated for carnivorous fishes cultured in commercial-scale tanks. Diets from a single feed producer were selected for comparison to control for variability that could be encountered between different manufacturers in terms of sources of dietary components used for formulations (e.g., protein quality). All three diets provided growth rates, FCEs, and survival rates that were comparable with those in other studies that have assessed production of juvenile cobia in RASs (Resley et al. 2006; Faulk et al. 2007; Webb et al. 2007). However, it is clear that the MG diet out-performed both of the other diets.

These results are not surprising considering the higher protein levels present in the MG diet as compared with the GOLD and HSB diets. They are surprising, however, when compared with the results of Craig et al. (2006), which indicated no significant difference in most production metrics of juvenile cobia fed six diets with varying protein and fat levels (levels that were similar to those used in the present study). The only difference those authors noted was a significantly lower feed efficiency in juveniles (initial weight $=7.4 \mathrm{~g}$ ) fed a diet with $50 \%$ protein compared with a $40 \%$ protein diet. This effect was not seen in their larger fish (mean initial weight $=49.3 \mathrm{~g}$ ), and we did not see this effect in our results with intermediatesized fish (mean initial weight $=29.2 \mathrm{~g}$ ). In fact, we
TABLE 4.- Selected dietary efficiency variables, hepatosomatic index (HSI), and intraperitoneal fat ratio (IPF) of juvenile cobia fed three different commercial diets for $56 \mathrm{~d}$ in recirculating aquaculture systems (see text for description of diets). Values (mean $\pm \mathrm{SE}$ ) within a row sharing the same letter are not significantly different $(P>0.05)$.

\begin{tabular}{lccc}
\hline & \multicolumn{3}{c}{ Diet } \\
\cline { 2 - 4 } \multicolumn{1}{c}{ Variable } & HSB & GOLD & MG \\
\hline $\begin{array}{l}\text { Energy retention (\%) } \\
\begin{array}{l}\text { Protein efficiency } \\
\text { ratio }\end{array}\end{array}$ & $24.8 \pm 0.6 \mathrm{y}$ & $26.1 \pm 0.4 \mathrm{y}$ & $32.7 \pm 0.3 \mathrm{z}$ \\
$\begin{array}{l}\text { Protein productive } \\
\text { value (\%) }\end{array}$ & $30.2 \pm 0.6 \mathrm{y}$ & $32.9 \pm 0.5 \mathrm{z}$ & $32.8 \pm 0.1 \mathrm{z}$ \\
$\begin{array}{l}\text { HSI (\%) } \\
\text { IPF (\%) }\end{array}$ & $4.95 \pm 0.18 \mathrm{z}$ & $5.33 \pm 0.15 \mathrm{z}$ & $4.29 \pm 0.13 \mathrm{y}$ \\
\hline
\end{tabular}

noted significantly higher FCE values for cobia fed the higher-protein MG diet. Our results are consistent with those of Chou et al. (2001), who demonstrated differences in growth and FCE with different levels of protein and lipid in the diet.

The present study, however, was not designed to directly assess the effect of protein or lipid levels on growth, since this has been well evaluated in cobia. Rather, the aim was to assess the effect of selected commercial diets administered in production-scale RASs on the production characteristics of juvenile cobia. It appears, though, that there is a lack of consistency between our production-scale $(8,000-\mathrm{L}$ tanks) results and the results of experimental studies by Craig et al. (2006), which were conducted in 110-L glass aquaria. Behaviorally, the cobia is a pelagic species and probably prefers a less-restrictive environment, such as the relatively large tanks used in our study. It is quite possible that, in studies conducted in small aquarium-sized tanks, even a small cobia would experience a greater degree of stress as a result of confinement. Alteration of production characteristics, such as growth rate, by chronic stress related to the restricted environment (Huntingford et al. 2006) could mask the dietary effects being measured in studies using aquarium-sized tanks. Environmental factors, such as shape of rearing environment and degree of confinement, have been shown to affect stress and production characteristics of fish (Barcellos et al. 2004; Barretto and Volpato 2004).

Based on the proximate composition of fish fed the three different diets, whole-body deposition of lipids was equivalent. However, there appeared to be a difference in the tissues where lipids were deposited. Fish fed the HSB and GOLD diets appeared to store energy in liver tissue based on their elevated HSI values, whereas the MG-fed fish were beginning to store lipid in the intraperitoneal tissues. Wang et al. 
(2005) noted a direct correlation between liver lipid levels and HSI values of juvenile cobia. In addition, the higher whole-body protein and PPV values of cobia fed the HSB diet may indicate a protein-sparing effect due to the higher dietary lipids. Protein sparing in highlipid diets has been well documented in fish nutrition (Halver and Hardy 2002). However, protein sparing in cobia has not been documented in previous studies that systematically compared the effects of protein and lipid levels on production characteristics (Chou et al. 2001; Wang et al. 2005; Craig et al. 2006).

Feed represents the largest variable cost component in the production of carnivorous fishes, and using an appropriately formulated ration is critical in keeping cost down and minimizing metabolic waste products (Craig et al. 2006). Although the high-protein MG diet in our study produced higher growth rates and FCE values, the actual cost of feed per kilogram of fish produced was US\$1.23 for MG, \$0.99 for HSB, and $\$ 0.99$ for GOLD. Given the calculated growth rates for each diet, the HSB diet would require an additional 11 $\mathrm{d}$ for fish to reach $310 \mathrm{~g}$ and fish fed the GOLD diet would require an additional $10 \mathrm{~d}$. The cost of cobia production based on use of MG would only be equivalent to the other diets if the faster growth rate compensated for the additional cost of operating the rearing system for $10-11 \mathrm{~d}$ (i.e., approximately a $15 \%$ reduction in rearing time).

\section{Conclusions}

The MG diet performed better than either the HSB or GOLD diet in terms of growth rate, weight gain, and FCE for the rearing of juvenile cobia from a 29.2-g starting weight to a final weight of over $200 \mathrm{~g}$. All three diets, however, performed well for rearing juvenile cobia. The difference in cost for rearing juvenile cobia with the MG diet rather than the HSB or GOLD diet could be compensated for by a $15 \%$ shorter production period.

\section{Acknowledgments}

Special appreciation is extended to Fernando Cavalin for providing daily care to experimental cobia before the rearing trial was initiated. Thanks are also extended to Jay Adams, Meghan Anderson, Daniel Benetti, David Cerino, Jerry Corsaut, Megan Davis, Don Freeman, David Haley, Susan Laramore, Rolland Laramore, Todd Lenger, Gary Luisi, Tim Pfeiffer, Bruno Sardenburg, Peter Stock, Patrick Tracy, Tony Wadley, and Peter Woodward for technical support. We also thank Jesse Chappel, Anita Kelly, and John Scarpa for providing critical reviews of the manuscript. This study was funded by the USDA-ARS under Project Number 6225-63000-007-00D. All programs and services of the USDA are offered on a nondiscriminatory basis without regard to race, color, national origin, religion, sex, age, marital status, or handicap. Mention of trade names or commercial products in this article is solely for the purpose of providing specific information and does not imply endorsement by the USDA.

\section{References}

AOAC (Association of Official Analytical Chemists). 2003. Official Methods of Analysis, 17th edition, 2nd revision. AOAC, Arlington, Virginia.

Arnold, C. R., J. B. Kaiser, and G. J Holt. 2002. Spawning of cobia, Rachycentron canadum, in captivity. Journal of the World Aquaculture Society 33(2):205-208.

Barcellos, L. J., L. C. Kreutz, R. M. Quevedo, I. Fioreze, L. Cericato, A. B. Soso, M. Fagundes, J. Conrad, R. K. Baldissera, A. Bruschi, and F. Ritter. 2004. Nursery rearing of jundiá, Rhamdia quelen (Quoy and Gaimard) in cages: cage type, stocking density and stress response to confinement. Aquaculture 232:383-394.

Barretto, R. E., and G. L. Volpato. 2004. Caution for using ventilatory frequency as an indicator of stress in fish. Behavioral Processes 66:43-51.

Benetti, D. D., M. R. Orhun, B. O'Hanlon, I. Zink, F. G. Cavalin, B. Sardenberg, K. Palmer, B. Denlinger, and D. Bacoat. 2007. Aquaculture of cobia in the Americas and the Caribbean. Pages 57-77 in I. C. Liao and E. M. Leaño, editors. Cobia aquaculture: research, developments and commercial production. Asian Fisheries Society, Manila.

Benetti, D. D., B. Sardenberg, A. Welch, R. Hoenig, M. Refik Orhun, and I. Zink. 2008. Intensive larval husbandry and fingerling production of cobia Rachycentron canadum. Aquaculture 281:22-27.

Bligh, E. G., and W. J. Dyer. 1959. A rapid method of total lipid extraction and purification. Canadian Journal of Biochemistry and Physiology 37:911-917.

Chen, B. S. 2001. Studies on the net-cage culture and disease control technology of cobia Rachycentron canadum. Sixth Asian Fisheries Forum Book of Abstracts, Asian Fisheries Society, Manila.

Chou, R.-L., B. Y. Her, M. S. Su, G. Hwang, Y. H. Wu, and H. Y. Chen. 2004. Substituting fish meal with soybean meal in diets of juvenile cobia Rachycentron canadum. Aquaculture 229:325-333.

Chou, R.-L., M.-S. Su, and H.-Y. Chen. 2001. Optimal dietary protein and lipid levels for juvenile cobia (Rachycentron canadum). Aquaculture 193:81-89.

Craig, S. R., M. H. Schwarz, and E. McLean. 2006. Juvenile cobia (Rachycentron canadum) can utilize a wide range of protein and lipid levels without impacts on production characteristics. Aquaculture 261:384-391.

De Silva, S. S., and M. H. Phillips. 2007. A review of cage aquaculture: Asia (excluding China). FAO (Food and Agriculture Organization of the United Nations) Fisheries Technical Paper 498:18-48.

Dodd, Q. 2001. U.S. cobia culture meets early success. Hatchery International (July/August):14-17.

Faulk, C. K., J. B. Kaiser, and G. J. Holt. 2007. Growth and survival of larval and juvenile cobia Rachycentron 
canadum in a recirculating raceway system. Aquaculture 270:149-157.

Franks, J. S., J. T. Ogle, J. N. Lotz, L. C. Nicholson, D.N. Barnes, and K. M. Larsen. 2001. Spontaneous spawning of cobia Rachycentron canadum induced by human chorionic gonadotropin with comments on fertilization, hatching, and larval development. Proceedings of the Gulf and Caribbean Fisheries Institute 52:598-609.

Halver, J. E., and R. W. Hardy. 2002. Fish nutrition, 3rd edition. Academic Press, San Diego.

Holt, G. J., C. K. Faulk, and M. H. Schwarz. 2007. A review of the larviculture of cobia Rachycentron canadum, a warm water marine fish. Aquaculture 268:181-187.

Huntingford, F. A., C. Adams, V. A. Braithwaite, S. Kadri, T. G. Pottinger, P. Sandøe, and J. F. Turnbull. 2006. Current issues in fish welfare. Journal of Fish Biology 68:332-372.

Kilduff, P., W. DuPaul, M. Osterling, J. Olney Jr., and J. Tellock. 2002. Induced tank spawning of cobia, Rachycentron canadum, and early larval husbandry. World Aquaculture 33(2):35-38.

Liao, I. C. 2003. Candidate species for open ocean aquaculture: the successful case of cobia Rachycentron canadum in Taiwan. Pages 205-213 in C. J. Bridger and B. A. Costa-Pierce, editors. Open ocean aquaculture: from research to commercial reality. World Aquaculture Society, Baton Rouge, Louisiana.

Liao, I. C., T. S. Huang, W. S. Tsai, C. M. Hsueh, S. L. Chang, and E. M. Leaňo. 2004. Cobia culture in Taiwan: current status and problems. Aquaculture 237:155-165.

Liao, I. C., H. M. Su, and E. Y. Chang. 2001. Techniques in finfish larviculture in Taiwan. Aquaculture 200:1-31.

Lunger, A. N., S. R. Craig, and E. McLean. 2006. Replacement of fish meal in cobia (Rachycentron canadum) diets using an organically certified protein. Aquaculture 257:393-399.

Lunger, A. N., E. McLean, and S. R. Craig. 2007a. The effects of organic protein supplementation upon growth, feed conversion and texture quality parameters of juvenile cobia (Rachycentron canadum). Aquaculture 264:342352.

Lunger, A. N., E. McLean, T. G. Gaylord, D. Kuhn, and S. R. Craig. 2007b. Taurine supplementation to alternative dietary proteins used in fish meal replacement enhances growth of juvenile cobia (Rachycentron canadum). Aquaculture 271:401-410.

McClane, A. J. 1974. McClane's new standard fishing encyclopedia and international angling guide. Holt, Rinehart and Winston, New York.

Oesterling, M. 2001. Cultured cobia satisfy tastebuds. Virginia Marine Resources Bulletin 33(2):23.

Pfeiffer, T. J., and R. F. Malone. 2006. Nitrification performance of a propeller-washed bead clarifier supporting a fluidized sand biofilter in a recirculating warmwater fish system. Aquacultural Engineering 31:80-92.

Resley, M. J., K. A. Webb Jr., and G. J. Holt. 2006. Growth and survival of juvenile cobia, Rachycentron canadum, at different salinities in a recirculating aquaculture system. Aquaculture 253:398-407.
Rickards, W. L. 2001. Sustainable cobia culture and fisheries. Virginia Sea Grant Publication VSG-01-07, Virginia Institute of Marine Science, Charlottesville.

Schwarz, M., S. R. Craig, E. McLean, and D. Mowry. 2004. Status of cobia research and production. Proceedings of the International Conference on Recirculating Aquaculture 5:115-116.

Shiau, C-Y. 2007. Biochemical composition and utilization of cultured cobia (Rachycentron canadum). Pages 147-156 in I. C. Liao and E. M. Leaño, editors. Cobia aquaculture: research, developments and commercial production. Asian Fisheries Society, Manila.

Smith, M. M. 1986. Rachycentridae. Pages 661-662 in M. M. Smith and P. C. Heemstra, editors. Smith's sea fishes. Springer-Verlag, Berlin.

Timmons, M. B., S. T. Summerfelt, and B. J. Vinci. 1998. Review of circular tank technology and management. Aquacultural Engineering 18:51-69.

Tucker, J. W. Jr. 1998. Marine fish culture. Kluwer Academic Publishers, Boston.

Wang, J. T., Y. J. Liu, L. X. Tian, K. S. Mai, Z. Y. Du, Y. Wang, and H. J. Yang. 2005. Effect of dietary lipid level on growth performance, lipid deposition, hepatic lipogenesis in juvenile cobia (Rachycentron canadum). Aquaculture 249:439-447.

Webb, K. A., G. M. Hitzfelder, C. K. Faulk, and G. J. Holt. 2007. Growth of juvenile cobia, Rachycentron canadum, at three different densities in a recirculating aquaculture system. Aquaculture 264:223-227.

Weirich, C. R., A. Segars, J. Bruce, and C. L. Browdy. 2003. Development and implementation of biosecurity protocols and procedures at the Waddell Mariculture Center. Pages 139-156 in C.-S. Lee, editor. Biosecurity in aquaculture production systems: exclusion of pathogens and other undesirables. Aquaculture Interchange Program, Oceanic Institute, Waimanalo, Hawaii.

Weirich, C. R., T. I. J. Smith, M. R. Denson, A. D. Stokes, and W. E. Jenkins. 2004. Pond rearing of larval and juvenile cobia, Rachycentron canadum, in the southeastern United States: initial observations. Journal of Applied Aquaculture 16:27-44.

Weirich, C. R., A. D Stokes, T. I. J. Smith, W. E. Jenkins, and M. R. Denson. 2006. Outdoor tank and pond pawning of cobia Rachycentron canadum in coastal South Carolina. Journal of Applied Aquaculture 18(3):1-16.

Zhou, Q.-C., K.-S. Mai, B.-P. Tan, and Y.-J. Liu. 2005. Partial replacement of fishmeal by soybean meal in diets for juvenile cobia (Rachycentron canadum). Aquaculture Nutrition 11:175-182.

Zhou, Q.-C., B.-P. Tan, K.-S. Mai, and Y.-J. Liu. 2004. Apparent digestibility of selected feed ingredients for juvenile cobia Rachycentron canadum. Aquaculture 241:441-451.

Zhou, Q.-C., Z. H. Wu, S. Y. Chi, and Q. H. Yang. 2007. Dietary lysine requirement of juvenile cobia (Rachycentron canadum). Aquaculture 273:634-640.

Zhou, Q.-C., Z. H. Wu, B.-P. Tan, S. Y. Chi, and Q. H. Yang. 2006. Optimal dietary methionine requirement for juvenile cobia (Rachycentron canadum). Aquaculture 258:551-557. 